\title{
In situ analysis of oxygen consumption and diffusive transport in 1 high-temperature acidic iron-oxide microbial mats
}

\section{Authors: Hans C. Bernstein, Jacob P. Beam, Mark A. Kozubal, Ross P. Carlson, \& William P. Inskeep}

NOTICE: This is the peer reviewed version of the following article: Bernstein HC, Beam JP, Kozubal MA, Carlson RP, Inskeep WP, "In situ analysis of oxygen consumption and diffusive transport in 1 high-temperature acidic iron-oxide microbial mats," Environ Microbiol 2013 15(8):2360-2370, which has been published in final form at http:// dx.doi.org/10.1111/1462-2920.12109. This article may be used for non-commercial purposes in accordance with Wiley Terms and Conditions for Self-Archiving

Bernstein HC, Beam JP, Kozubal MA, Carlson RP, Inskeep WP, "In situ analysis of oxygen consumption and diffusive transport in 1 high-temperature acidic iron-oxide microbial mats," Environ Microbiol 2013 15(8):2360-2370 


\section{In situ analysis of oxygen consumption and diffusive transport in high-temperature acidic iron-oxide microbial mats}

\author{
Hans C. Bernstein, ${ }^{1,3 \dagger}$ Jacob P. Beam, ${ }^{2,4 \dagger}$ \\ Mark A. Kozubal, ${ }^{2,4}$ Ross P. Carlson ${ }^{1,3,4}$ and \\ William P. Inskeep ${ }^{2,4 *}$ \\ ${ }^{1}$ Department of Chemical and Biological Engineering, \\ ${ }^{2}$ Department of Land Resources and Environmental \\ Sciences, ${ }^{3}$ Center for Biofil Engineering, and ${ }^{4}$ Thermal \\ Biology Institute, Montana State University, Bozeman, \\ MT 59717, USA.
}

\section{Summary}

The role of dissolved oxygen as a principal electron acceptor for microbial metabolism was investigated within $\mathrm{Fe}$ (III)-oxide microbial mats that form in acidic geothermal springs of Yellowstone National Park (USA). Specifi goals of the study were to measure and model dissolved oxygen profile within hightemperature $\left(65-75^{\circ} \mathrm{C}\right)$ acidic $(\mathrm{pH}=2.7-3.8) \mathrm{Fe}(\mathrm{III})-$ oxide microbial mats, and correlate the abundance of aerobic, iron-oxidizing Metallosphaera yellowstonensis organisms and mRNA gene expression levels to $\mathrm{Fe}(\mathrm{II})$-oxidizing habitats shown to consume oxygen. In situ oxygen microprofile were obtained perpendicular to the direction of convective flo across the aqueous phase/Fe(III)-oxide microbial mat interface using oxygen microsensors. Dissolved oxygen concentrations dropped from $\sim 50-60 \mu \mathrm{M}$ in the bulkfluid/ma surface to below detection $(<0.3 \mu \mathrm{M})$ at a depth of $\sim 700 \mu \mathrm{m}(\sim 10 \%$ of the total mat depth). Net areal oxygen fluxe into the microbial mats were estimated to range from $1.4-1.6 \times 10^{-4} \mu \mathrm{mol} \mathrm{cm} \mathrm{cm}^{-2} \mathrm{~s}^{-1}$. Dimensionless parameters were used to model dissolved oxygen profile and establish that mass transfer rates limit the oxygen consumption. A zone of higher dissolved oxygen at the mat surface promotes Fe(III)-oxide biomineralization, which was supported using molecular analysis of Metallosphaera yellowstonensis 16S rRNA gene copy numbers and mRNA expression of haem $\mathrm{Cu}$ oxidases (FoxA) associated with $\mathrm{Fe}$ (II)-oxidation.

\section{Introduction}

Yellowstone National Park (YNP), Wyoming, USA contains a diverse collection of pristine high-temperature environments containing stable thermophilic microbial communities. Acidic $(\mathrm{pH} \sim 3)$, amorphous $\mathrm{Fe}(\mathrm{III})$ oxyhydroxide microbial mats located in Norris Geyser Basin (NGB) are of particular interest due to the interplay between geochemical cycling, nutrient transport, and unique microbial metabolic capabilities associated with dominant community members of the domain Archaea (Jackson et al., 2001; Inskeep et al., 2004; 2005; 2010; Macur et al., 2004; Inskeep and McDermott, 2005; Kozubal et al., 2008; 2011). Both autotrophic and heterotrophic Fe-metabolizing community members have been isolated and observed in metagenomes from $\mathrm{Fe}(\mathrm{III})$ oxide mats in NGB (Kozubal et al., 2008; 2012b; Inskeep et al., 2010). Of these, Fe-oxidizing Metallosphaera yellowstonensis-like organisms have been shown to comprise near $20 \%$ of the total archaeal community in numerous Fe(III)-oxide microbial mats (Kozubal et al., 2008). M. yellowstonensis is known to utilize dissolved $\mathrm{O}_{2}$ as the principal terminal electron acceptor via a haem $\mathrm{Cu}$ oxidase (FoxA) associated with the Fox terminal oxidase complex (Kozubal et al., 2008; 2011). An additional Fe-metabolizing community member (Sulfolobales strain MK5) has been characterized and found to be a heterotrophic $\mathrm{Fe}(\mathrm{II})$-oxidizer and $\mathrm{Fe}(\mathrm{III})$-reducer under aerobic and anaerobic conditions, respectively (Kozubal et al., $2012 b)$. Other dominant organisms in Fe-oxide mat communities include a deeply rooted archaeal lineage also thought to utilize $\mathrm{O}_{2}$ based on analysis of respiratory pathways (Kozubal et al., 2012a). The growth and development of $\mathrm{Fe}$ (III)-oxide microbial mats is likely influence by the availability of electron donors and acceptors (and/or other key nutrients) present within the mat microenvironments. The mass transfer of dissolved $\mathrm{O}_{2}$ to and within the $\mathrm{Fe}$ (III)-oxide microbial mat is of specifi interest due to the $\mathrm{O}_{2}$ requirement of microbially mediated $\mathrm{Fe}(\mathrm{II})$-oxidation as well as aerobic oxidation of organic carbon (organotrophy) and arsenite (Hamamura et al., 2009). 
Iron-oxidizing microorganisms are also important in deep sea hydrothermal vents, acid mine drainages, seeps, and other geothermal springs (Emerson and Revsbech, 1994a; Emerson and Moyer, 2002; Baker and Banfield 2003; Inskeep et al., 2004). Several neutrophilic $\mathrm{Fe}(\mathrm{II})$-oxidizing microbial mat communities and structures have been characterized in situ using microsensors to evaluate gradients in oxygen (Emerson and Revsbech, 1994a,b; Sobolev and Roden, 2001; Druschel et al., 2008). Typically, these studies have reported $\mathrm{O}_{2}$ gradients extending from the oxic bulk-flui interface towards anoxic regions. Microsensors (or microelectrodes) represent a reasonably non-invasive approach for measuring concentration profile of dissolved $\mathrm{O}_{2}$ and other chemical gradients in situ (Revsbech and Jorgensen, 1986).

Amorphous Fe(III)-As(V) oxyhydroxide microbial mats from NGB have been shown to form as a result of microbial activity (Inskeep et al., 2004). The rate of abiotic Fe(II)oxidation is very slow at low $\mathrm{pH}(<4.5)$ (Singer and Stumm, 1970; Konhauser, 1998). Moreover, M. yellowstonensis strain MK1 has been shown to be highly relevant in these habitats and oxidizes Fe(II) in pure culture (Kozubal et al., 2008). Rapid microbial oxidation of As(III) to As(V) has also been observed in the outflo channels of these acidic hot springs, and which has been linked with the expression of arsenite oxidase genes (Langner et al., 2001; Macur et al., 2004; Hamamura et al., 2009). These microbial mats are comprised of fairly porous $\mathrm{Fe}$ (III)-oxides that form on rhyolitic parent material and are essentially equivalent to biofil structures (Hall-Stoodley et al., 2004). In other aerobic biofilms it has been established that the transport of dissolved $\mathrm{O}_{2}$ from the bulk flui is influence by the physical and structural properties of the biofil matrix (de Beer et al., 1994). Similarly, the consumption of dissolved $\mathrm{O}_{2}$ and subsequent $\mathrm{Fe}$ (III)-oxide biomineralization rates in acidic geothermal systems are controlled by a combination of reaction kinetics (principally associated with microbial metabolism) and mass transport processes originating from the overlying gaseous oxygen $\left(p_{\mathrm{O}_{2}} \approx 0.16 \mathrm{~atm}\right.$ at this elevation). Few studies have coupled in situ $\mathrm{O}_{2}$ microprofile with the depth-wise distribution and transcriptional activity of a microbial community, especially in geothermal microbial mats.

Metallosphaera yellowstonensis is an $\mathrm{Fe}(\mathrm{II})$-oxidizing Sulfolobales abundant in acidic, high-temperature Fe(III)- oxide microbial mats in YNP, however, little is known regarding the distribution of these organisms with depth into the mat. It was previously shown that $M$. yellowstonensis is an obligate aerobe and actively transcribes its foxA gene within NGB geothermal springs (Kozubal et al., $2008 ; 2011$ ). The foxA gene encodes for subunit I (haem $\mathrm{Cu}$ oxidase, $\mathrm{HCO}$ ) of a terminal oxidase complex that is specifi for the oxidation of ferrous Fe (Bathe and Norris, 2007). Thus, this gene is essential as the fina step of oxygen reduction in the electron transport chain of $\mathrm{Fe}(\mathrm{II})$ oxidation in M. yellowstonensis (Kozubal et al., 2011). The foxA gene has also been identifie in other ironoxidizing Sulfolobales (Bathe and Norris, 2007; Auernik and Kelly, 2008).

The current study focuses on in situ $\mathrm{O}_{2}$ analysis as a function of depth in high-temperature $\mathrm{Fe}$ (III)-oxide mats to evaluate the extent and possible mechanisms of microbial $\mathrm{O}_{2}$ consumption in archaeal-dominated communities. The specifi aims of this study were to (i) measure in situ dissolved oxygen profile within high-temperature acidic $\mathrm{Fe}$ (III)-oxide microbial mats, (ii) quantitatively compare $\mathrm{O}_{2}$ mass transfer and consumption rates with rates of $\mathrm{Fe}$ (III)-oxide biomineralization, and (iii) link population abundance and mRNA gene expression levels of Metallosphaera yellowstonensis to $\mathrm{Fe}(\mathrm{II})$-oxidizing habitats shown to consume $\mathrm{O}_{2}$.

\section{Results}

\section{Oxygen microprofile}

The concentration of dissolved $\mathrm{O}_{2}$ declined significantl as a function of depth in high-temperature Fe(III)-oxide mats (Fig. 1) from approximately $40-70 \mu \mathrm{M}$ in the stream water to below detection $(<0.3 \mu \mathrm{M})$ at depths ranging from 400 to $750 \mu \mathrm{m}$ (Fig. 2, Table 1). Oxygen was detected to depths of 250-1300 $\mu \mathrm{m}$ in Beowulf (BE_D) iron mats. An average depth of $730 \pm 500 \mu \mathrm{m}$ was obtained from three oxygen profile located within a $2 \mathrm{~cm}$ radius. Depths of $\mathrm{O}_{2}$ penetration were more similar among replicates measured at One Hundred Springs Plain (OSP_B), and averaged $800 \pm 88 \mu \mathrm{m}$. Based on a measured total mat thickness $\left(L_{f}\right)$ of $\sim 7 \mathrm{~mm}$, these results show that detectable levels of oxygen were observed in the top $\sim 10 \%$ of the $\mathrm{Fe}(\mathrm{III})$-oxide microbial mat.

Table 1. Select aqueous geochemistry at sampling positions (BE_D and OSP_B) within Beowulf and OSP Springs, Norris Geyser Basin (YNP).

\begin{tabular}{llllllll}
\hline Site & $\mathrm{pH}$ & $\mathrm{pH}(\mathrm{Mat})$ & Temperature $\left({ }^{\circ} \mathrm{C}\right)$ & $\mathrm{DS}(\mu \mathrm{M})$ & $\mathrm{O}_{2}(\mathrm{aq}), \mu \mathrm{M}$ & $\mathrm{CO}_{2}(\mathrm{aq}), \mu \mathrm{M}$ & $\mathrm{Fe}(\mathrm{TS}), \mu \mathrm{M}$ \\
\hline BE_D & $3.0(0.1)$ & 2.7 & $68(2)$ & $6(4)$ & $60(20)$ & $800(322)$ & $39(5)$ \\
OSP_B & $3.4(0.1)$ & 3.75 & $75(2)$ & $4(2)$ & $51(12)$ & $340(221)$ & $32(8)$ \\
\hline
\end{tabular}

Values represent multiple sampling times corresponding to the study period over two summer seasons (2010-2011).

Standard deviations are in parentheses $(n=4)$.

DS, dissolved sulfide $\mathrm{Fe}(\mathrm{TS})$, total soluble $\mathrm{Fe}$ (essentially $98 \%$ ferrous-Fe). 


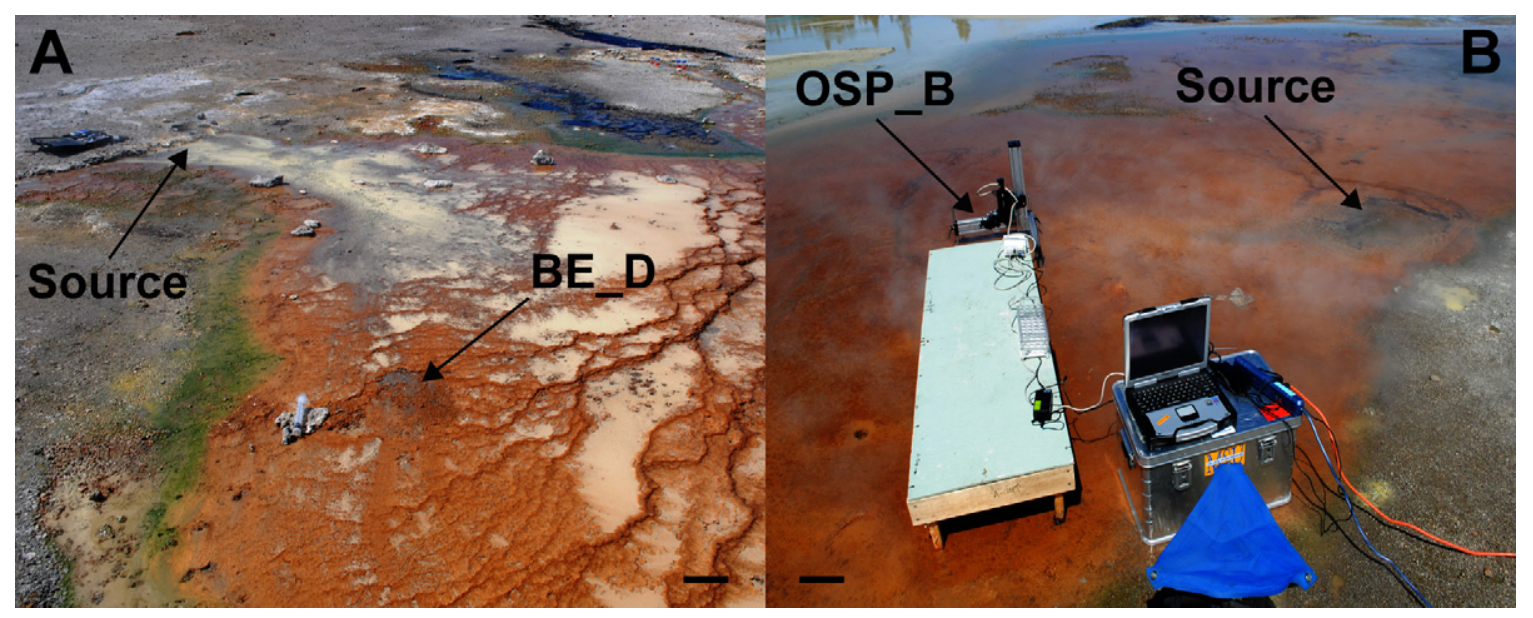

Fig. 1. Photographs of sampling sites at (A) Beowulf Spring (BE) and (B) One-Hundred Springs Plain (OSP). Arrows represent approximate positions where aqueous geochemical and solid phases were sampled for molecular analysis and where oxygen microsensor measurements were obtained (scale bar $=20 \mathrm{~cm}$ ).

Dissolved $\mathrm{O}_{2}$ profile from both sites (Beowulf and OneHundred Springs Plain) show the zones of most rapid concentration change near the surface of the mat (Fig. 2). The predominant concave curvature of all $\mathrm{O}_{2}$ profile implies that there was no and/or negligible amounts of $\mathrm{O}_{2}$ being produced and evolved from the mat. Although some $\mathrm{O}_{2}$ profile exhibited minor inflection in curvature, these are likely due to flow-oriente laminations (i.e. thin layers exhibiting variable $\mathrm{O}_{2}$ consumption rates) and structural heterogeneity (i.e. channels and voids) observed as a function of mat depth (Fig. 3). Dissolved $\mathrm{O}_{2}$ measurements made at different water column depths above the Fe-oxide mat surface were fairly constant $(60 \pm 15 \mu \mathrm{M})$ indicating that the stream water above the mat is wellmixed and below the measured $\mathrm{O}_{2}$ saturation $(100 \mu \mathrm{M}$; see Experimental procedures). Moreover, these measurements did not have the resolution to identify a diffusive boundary layer (DBL). The DBL thickness is primarily a function of velocity. Measured surface velocities over the
Fe mats were high (5-20 $\left.\mathrm{cm} \mathrm{s}^{-1}\right)$, and mass transfer limitations external to the Fe mat were assumed negligible. The observed transition from a well-mixed bulk liquid to a depth-dependent $\mathrm{O}_{2}$ concentration profil suggest that diffusion is the primary mechanism of mass transport within the $\mathrm{Fe}$ (III)-oxide mat.

Fick's law was used to calculate the net flu of dissolved $\mathrm{O}_{2}$ into the near surface of the $\mathrm{Fe}$ (III)-oxide mat using measured oxygen concentration profile and the linear portions of the profil that span the aqueous-mat interface. Diffusion coefficients for dissolved $\mathrm{O}_{2}$ in water were estimated to be $6.1 \times 10^{-5}$ and $6.2 \times 10^{-5} \mathrm{~cm}^{2} \mathrm{~s}^{-1}$ at $68^{\circ} \mathrm{C}$ and $75^{\circ} \mathrm{C}$ (BE_D and OSP_B, respectively) using the Wilke-Chang correlation (Wilke and Chang, 1955). The calculated $\mathrm{O}_{2}$ flu values were $1.64 \times 10^{-4}$ and $1.41 \times 10^{-4} \mu \mathrm{mol} \mathrm{O} \mathrm{cm}^{-2} \mathrm{~s}^{-1}$ for BE_D and OSP_B, respectively. Assuming steady-state, these values represent a net areal rate of $\mathrm{O}_{2}$ consumption by the Fe-oxide microbial mats.
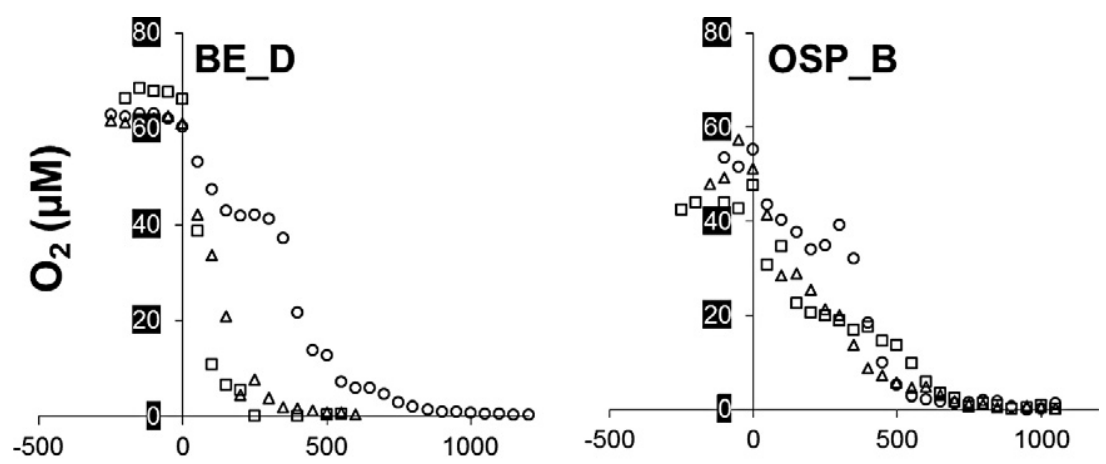

\section{Depth $(\mu \mathrm{m})$}

Fig. 2. Dissolved $\mathrm{O}_{2}$ microprofile measured at sampling locations (BE_D and OSP_B) within Beowulf and OSP geothermal springs. Each plot contains 3 individual profile taken at different positions within $\mathrm{a} \sim 2 \mathrm{~cm}$ radius (individual data points were measured in $50 \mu \mathrm{m}$ step sizes; $x$ (depth) $=0$ corresponds with the mat surface). 


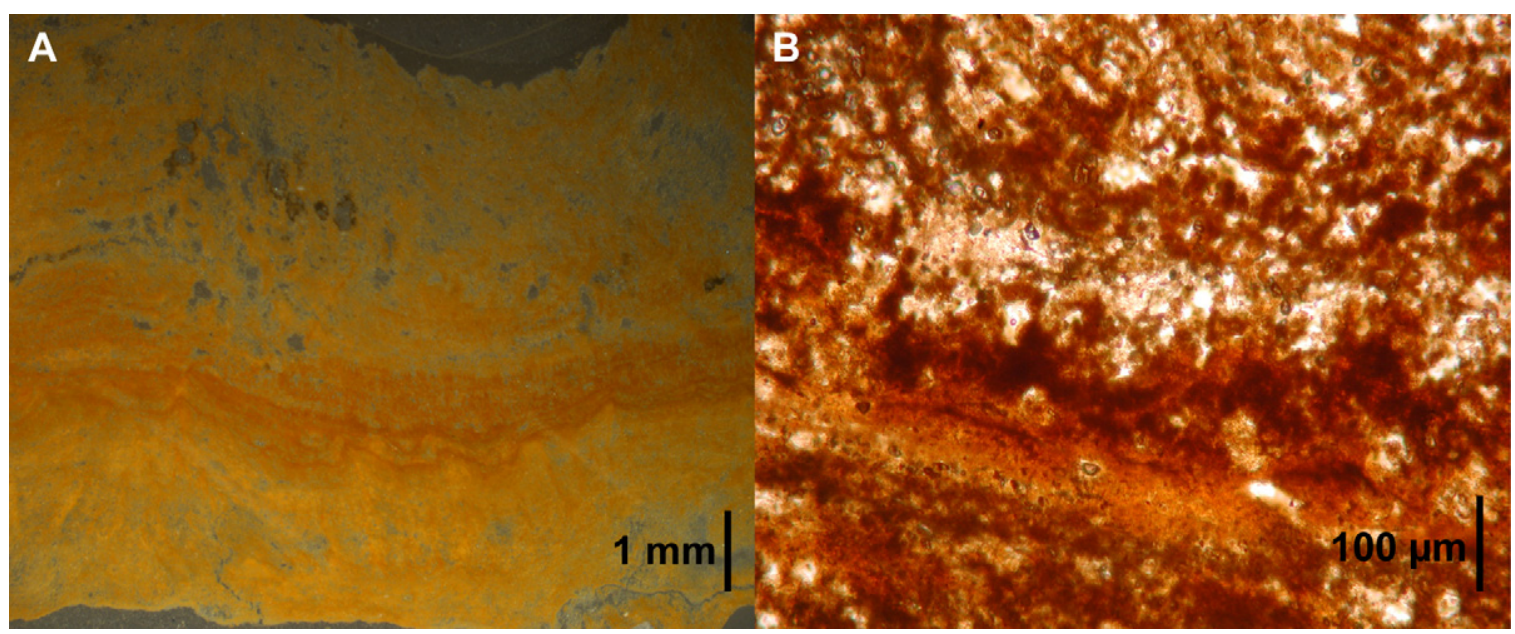

Fig. 3. Stereo-micrographs of epoxy embedded thin sections of BE_D iron-oxide microbial mat cut perpendicular to the bulk stream flo . Orientated visual structural variations (e.g. laminations and voids) represent heterogeneity in the $\mathrm{Fe}(\mathrm{III})$-oxide mat structure.

A. Full-scaled image of an excised bulk-mat sample.

B. Fine-scaled image of laminated portion of a second excised bulk-mat sample.

\section{Reaction-diffusion analysis}

Oxygen profile were used to fi steady-state reactiondiffusion models assuming either firs or zero-order kinetics (Eqs 1 and 2) using profil data scaled to the unitless parameters $u$ (dimensionless concentration) and $\zeta$ (dimensionless depth-position) (see Experimental procedures). A concentration-dependent (first-order model fi the data from both sites ( $R^{2}$ values $\left.\geq 0.96\right)$ compared with poor fit using a zero-order model $\left(R^{2}<0.5\right.$, data not shown). Consequently, the $\mathrm{O}_{2}$ consumption rates are best described with concentration-dependent kinetics (Fig. 4). The first-orde Thiele modulus $\phi_{1}$ (see Experimental procedures and Appendix S1) is define as a ratio of the reaction to diffusion time scales and was used as the single fittin parameter for modelling experimental dissolved $\mathrm{O}_{2}$ profiles Values of the fitte first-orde Thiele moduli ranged from $\sim 30$ to 60 (OSP_B and BE_D profiles respectively), suggesting that under these conditions, the reaction time-scale is an order of magnitude greater than the diffusion time-scale. Consequently, the rate of microbial oxygen consumption is likely controlled by the diffusion rate of dissolved oxygen in the mat.

\section{$\mathrm{Fe}(\mathrm{III})$-oxide accretion rates}

The rate of $\mathrm{Fe}$ (III)-oxide deposition was determined in situ using glass slides $(75 \times 25 \times 1 \mathrm{~mm})$ (Fig. S1) introduced and analysed during the study period corresponding to $\mathrm{O}_{2}$ profil measurements. The amount of $\mathrm{Fe}$ (III)-oxide accumulated on the slide surface increased linearly over 133 days (Fig. 5), resulting in measured $\mathrm{Fe}$ (III)-oxide accumulation rates of $0.4 \times 10^{-5}$ and $3.0 \times 10^{-5} \mu \mathrm{mol} \mathrm{Fe} \mathrm{cm}{ }^{-2} \mathrm{~s}^{-1}$ for BE_D and OSP_B, respectively. Aqueous Fe(III) was also produced as a direct result of $\mathrm{Fe}(\mathrm{II})$ oxidation at these spring positions and was as much as $5-10 \%$ of the total aqueous Fe (Table 1) (Inskeep et al., 2004; Macur et al., 2004; Kozubal et al., 2012b). Electron micrographs of material accumulated in OSP_B show cell attachment within 7 days of incubation, formation of amorphous
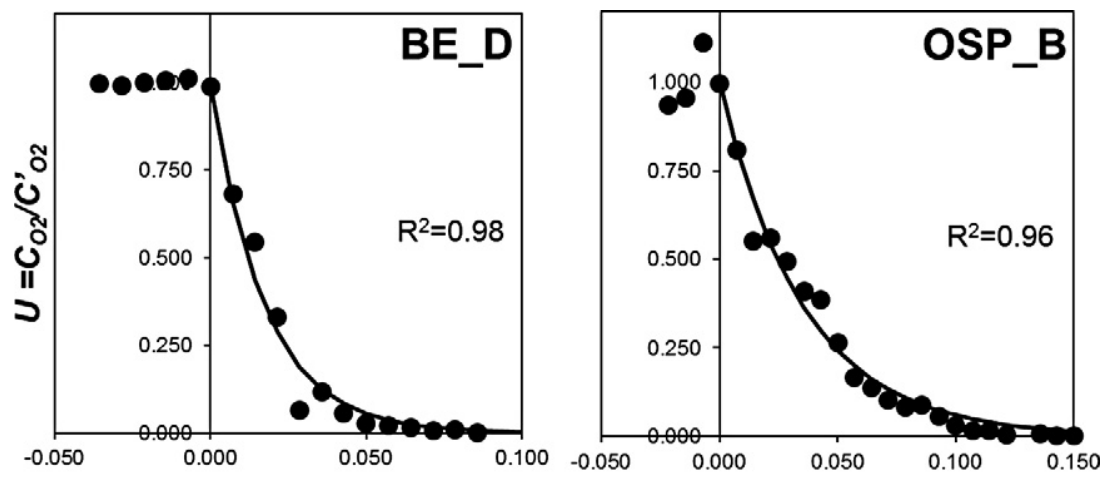

Fig. 4. Representative dissolved $\mathrm{O}_{2}$ microprofile expressed in terms of dimensionless parameters $u$ and $\zeta$ (also see Experimental procedures). Solid lines represent the fitte reaction diffusion models assuming a first-orde rate equation (Eq. 1) and optimized values of the Thiele modulus $\left(\varphi_{1}\right)$ to maximize $R^{2}$ values. The models are limited to spatial regions define by $\zeta \geq 0$, corresponding to positions inside the $\mathrm{Fe}$ (III)-oxide mat matrix. 


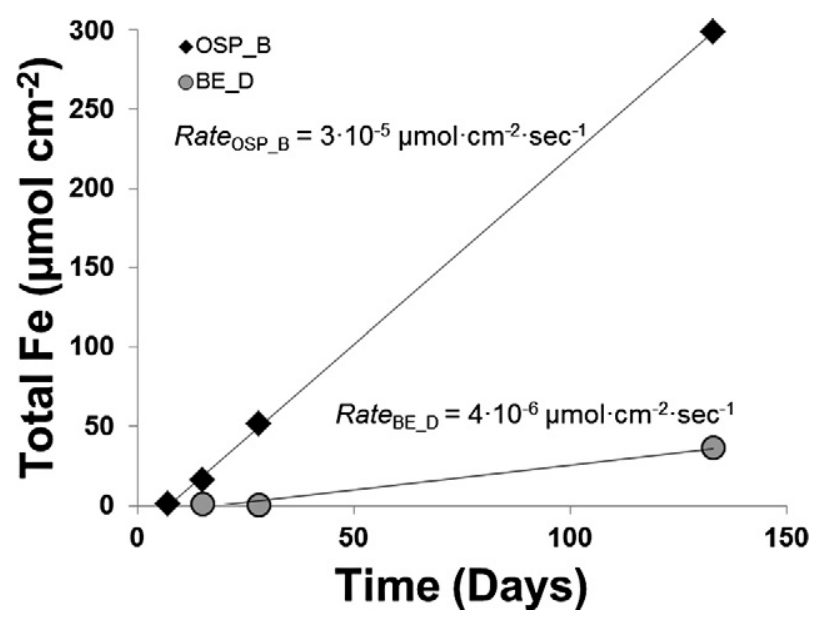

Fig. 5. Total iron accumulation on glass microscope slides incubated in situ for 133 days. Slopes of the linear accretion curves represent the net iron accumulation rates (Rate BE_D $_{-}$and Rate $_{O P_{-} B}$ ).

$\mathrm{Fe}(\mathrm{III})$-oxide within 14 days and complete slide coverage within 30-45 days depending on site (Macur et al., 2004; Beam et al., 2011). The heterogeneous Fe(III)-oxide surfaces forming at the aqueous/mat interface are replete with Fe-encrusted cells resulting from the oxidation of $\mathrm{Fe}$ (II) (Fig. 6), and reveal the type of surface in which oxygen microsensors were introduced. Previous analysis of the Fe(III)-oxide mats in NGB have shown that the predominant $\mathrm{Fe}$ phases formed in these systems are amorphous $\mathrm{Fe}(\mathrm{III})$-oxyhydroxides containing significan levels of sorbed arsenate $\left(A s^{\vee}:\right.$ Fe ${ }^{\text {III }}$ mole ratios $\sim 0.65$ ) (Inskeep et al., 2004). Measured rates of Fe(III)-oxide accumulation represent the total rate of $\mathrm{Fe}(\mathrm{III})$ produced minus any aqueous $\mathrm{Fe}(\mathrm{III})$ and $\mathrm{Fe}(\mathrm{III})$-oxides that are reduced or transported away in the stream channel (discussed further below). Accumulation of $\mathrm{Fe}$ (III)-oxide on the slides due to erosion from upstream sources is neg- ligible, in part because there is a direct linkage between cell surfaces and Fe(III)-oxide mineralization. The measured net vertical growth $\left(L_{\mathrm{f}}=\right.$ mat depth) of the Fe(III)oxide microbial mat was $\sim 7 \mathrm{~mm}$ (after 133 days of in situ incubation at the OSP_B site). Similarly, the measured $L_{f}$ at $B E \_D$ ranges from $\sim 5-10 \mathrm{~mm}$ determined by direct measurement of the native mat and epoxy embedded thin sections (Fig. 3). Although the absolute mat depth varies across $\mathrm{cm}$ scales, localized microsensor (50 $\mu \mathrm{m}$ diameter) measurements were made in mats with average thicknesses of $\sim 7 \mathrm{~mm}$ at both sites.

\section{Vertical distribution and activity of $\mathrm{M}$. yellowstonensis}

Metallosphaera yellowstonensis has been well established as an active and abundant Fe(II)-oxidizing Sulfolobales in acidic, geothermal Fe(III)-oxide microbial mats in NGB (Kozubal et al., 2008; 2011). Microbial mats subjected to $\mathrm{O}_{2}$ profil measurements were sampled and dissected to remove top and bottom samples (see Experimental procedures), and to establish a direct linkage between the presence of this population and measured $\mathrm{Fe}$ (III)-oxide deposition. Significan numbers of M. yellowstonensis were observed in all Fe-mat samples, and quantitative estimates of 16S rRNA gene copy number were higher in the top $1 \mathrm{~mm}$ of mat (bulk-liquid/mat interface) at both sampling sites. This result was more evident at OSP_B where 16S rRNA gene copy numbers ranged from $2.3 \pm 0.1$ to $0.7 \pm 0.1 \times 10^{5}$ per gram in top and bottom mat samples respectively. At BE_D, gene copy numbers for $M$. yellowstonensis ranged from $5.5 \pm 1.2 \times 10^{5}$ to $4.9 \pm 0.6 \times 10^{5}$ per gram in top and bottom mat samples respectively (Fig. 7A).

Corresponding Fe(III)-oxide mat samples were also used to obtain semi-quantitative estimates of M. yellowstonensis-like foxA mRNA transcripts using

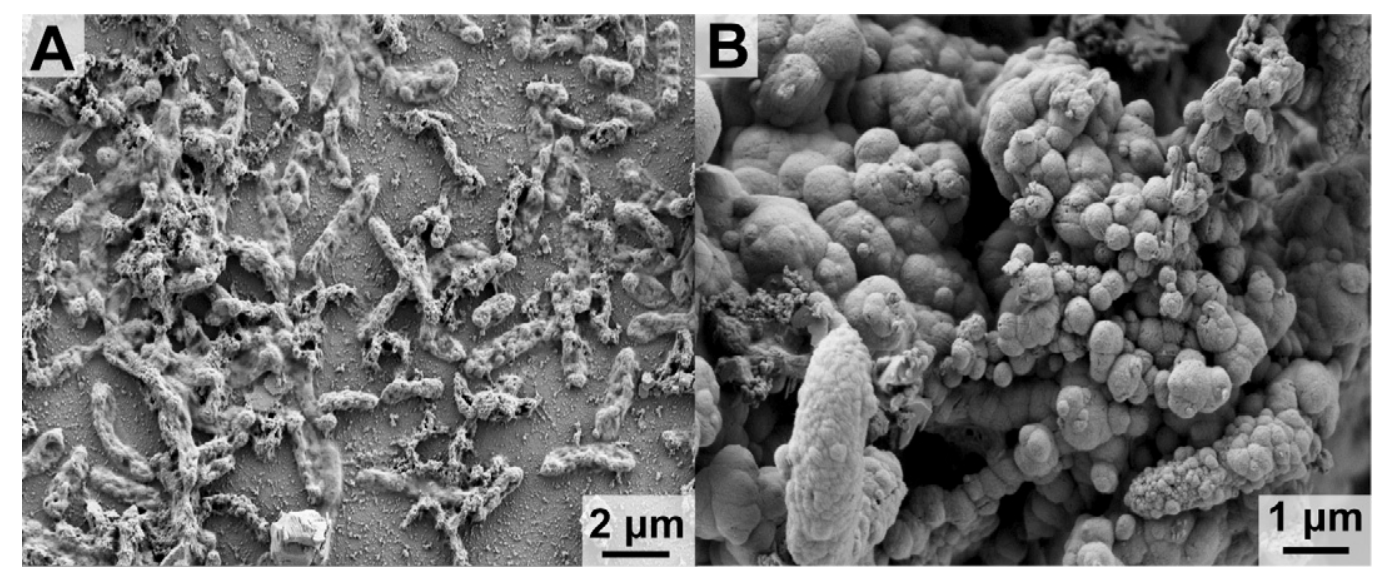

Fig. 6. SEM micrographs of glass slides incubated in the OSP_B site.

A. Attached cells observed after 1 week.

B. Mature amorphous Fe(III)-oxyhydroxide mat showing encrusted cells and ubiquity of biomineralized Fe(III)-oxides after 2 weeks. 

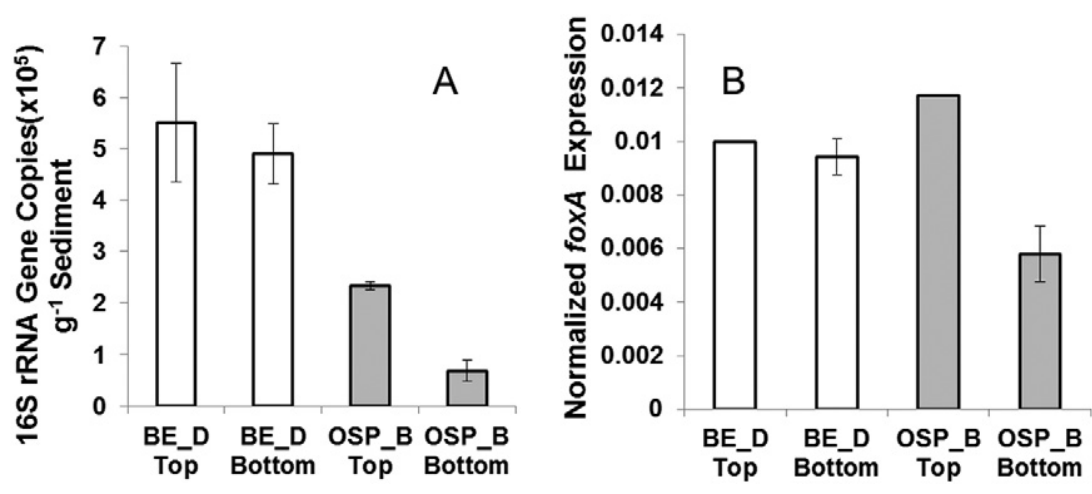

Fig. 7. (A) Spatial distribution of M. yellowstonensis 16S rRNA gene copies and (B) relative expression of foxA mRNA to 16S rRNA gene copies in BE D and OSP B. The designations 'Top' refers to the firs $1 \mathrm{~mm}$ of mat material at the mat/bulk-liquid interface; 'bottom mat' refers to the remainder of the mat. $P$-values: $(A)=0.46$ and $9.6 \times 10^{-5}$ for BE_D and OSP_B respectively, and (B) $=0.13$ and 0.005 for BE_D and OSP_B respectively. Error bars represent \pm 1 standard deviation from three technical replicates.

reverse transcriptase (RT)-PCR. foxA gene transcripts (mRNA) were observed in $\mathrm{Fe}(\mathrm{III})$-oxide mats from both sites (semi-quantitative estimates are normalized to $16 \mathrm{~S}$ rRNA gene copy number, Fig. 7B), and trends among the two sites and mat depths were similar to those observed using estimates of $M$. yellowstonensis 16S gene copy number. Specificall, foxA gene transcripts (mRNA) were also higher in top versus bottom mat samples from OSP_B (Fig. 7B). Normalized foxA transcript levels in BE_D were similar between top $\left(1.00 \pm 0 \times 10^{-2}\right)$ and bottom $\left(0.94 \pm 0.05 \times 10^{-2}\right)$ mat samples, suggesting that M. yellowstonensis-like organisms were still active in lower mat regions. These expression values agree with those found for $M$. sedula and $M$. yellowstonensis in pure culture grown on $\mathrm{Fe}(\mathrm{II})$ as the sole electron donor (Kappler et al., 2005; Kozubal et al., 2011). Among all $\mathrm{Fe}(\mathrm{III})$-oxide samples evaluated, the top $1 \mathrm{~mm}$ of the OSP_B mat showed the highest localized $\mathrm{O}_{2}$ concentrations $(\sim 50-70 \mu \mathrm{M})$, greater M. yellowstonensis 16S rRNA gene copy numbers, and higher amounts of $M$. yellowstonensis foxA mRNA.

\section{Discussion}

\section{Contributions to biological oxygen consumption}

High-temperature acidic Fe(III)-oxide microbial mats are reactive $\mathrm{O}_{2}$ sinks. The net areal oxygen consumption rates estimated from the measured microprofile encompass the sum of all oxygen-consuming reactions occurring in situ. The microbial populations present in hightemperature acidic Fe(III)-oxide mats from Norris Geyser Basin have been studied in considerable detail (e.g. Inskeep et al., 2010; Kozubal et al., 2012a,b) and results from these efforts form a basis for interpreting $\mathrm{O}_{2}$ consumption observed in the current study. The microbial processes that contribute to $\mathrm{O}_{2}$ consumption in these systems include the aerobic oxidation of electron donors such as reduced-C, Fe(II), As(III), hydrogen and reduced sulfur (e.g. sulfid and/or elemental S). Of these possible electron donors, those likely to be responsible for the majority of $\mathrm{O}_{2}$ consumption include reduced-C, $\mathrm{Fe}(\mathrm{II})$, and As(III), based on the concentrations measured in situ. Organic carbon utilized by aerobic chemoorganotrophs (Table 2) likely originates from three sources: decaying biomass of autotrophic microorganisms (e.g. M. yellowstonensis), dissolved organic carbon from source waters $(\sim 50 \mu \mathrm{M} \mathrm{C})$, and exogenous inputs from the local landscape (e.g. atmosphere, plant, animal, soil). Although highly exergonic, the concentrations of other electron donors (hydrogen, reduced $\mathrm{S}$, methane) are too low to support significan $\mathrm{O}_{2}$ consumption (Inskeep et al., 2005).

The rates of $\mathrm{Fe}(\mathrm{III})$-oxide deposition (e.g. $3 \times 10^{-5} \mu \mathrm{mol} \mathrm{Fe} \mathrm{cm}^{-2} \mathrm{~s}^{-1}$ at OSP_B) were used to estimate the $\mathrm{O}_{2}$ flu required to account for this fraction of total $\mathrm{Fe}(\mathrm{II})$ oxidation. It is understood that the actual oxygen flu attributable to the total $\mathrm{Fe}$ (II) oxidation rate in these systems will be higher, because some Fe(II) oxidized is lost as aqueous Fe(III), eroded as Fe(III)-oxides in the stream channel, and/or lost due to reductivedissolution. For OSP_B, the amount of oxygen consumed by $\mathrm{Fe}(\mathrm{II})$ oxidation, specificall resulting in $\mathrm{Fe}(\mathrm{III})$-oxide solids accumulated, was estimated at $5.3 \%$ of the total measured $\mathrm{O}_{2}$ flu [1 $\mathrm{mol} \mathrm{Fe}(\mathrm{II})$ requires $0.25 \mathrm{~mol} \mathrm{O}_{2}$ ]. The estimates are an order of magnitude lower at BE_D (only $0.61 \%$ of the measured $\mathrm{O}_{2}$ flu can be attributed to $\mathrm{Fe}(\mathrm{III})$ oxide deposition). The lower values at BE_D are due in part to higher stream channel velocities in Beowulf Spring $\left(\sim 14-20 \mathrm{~cm} \mathrm{~s}^{-1}\right)$, which results in greater erosion of $\mathrm{Fe}(\mathrm{III})$-oxide particles. The OSP site discharges on a lower slope than Beowulf Spring resulting in a shallower water column with lower channel velocities $(\sim 6-$ $\left.10 \mathrm{~cm} \mathrm{~s}^{-1}\right)$. Shear forces from bulk liquid flo coupled with photo-reduction and dissolution are both potential mechanisms for Fe(III)-oxide material loss, but the lower velocities in OSP Spring suggest that $\mathrm{Fe}$ (III)-oxide deposition rates measured at OSP_B are closer to an upper value of the contribution of $\mathrm{Fe}(\mathrm{II})$-oxidation to $\mathrm{O}_{2}$ flu $(\sim 5 \%)$. These estimates are reasonably consistent with the abundance of $M$. yellowstonensis like organisms in BE and OSP determined from prior studies (Kozubal et al., 2008; 
Table 2. Estimates of abundance of predominant taxa determined in iron oxide mat samples (BE_D and OSP_B) taken at similar locations to those used for oxygen microelectrode profiles

\begin{tabular}{lccc}
\hline Site/population & Estimated abundance ${ }^{\mathrm{a}}$ & $\mathrm{HCO}^{\mathrm{b}}$ & Reference \\
\hline OSP_B (T=75 C, pH=3.5) & & & Kozubal et al. (2012a,b) \\
Novel Archaeal Group 1 & $50-60$ & $\mathrm{Y}$ & Kozubal et al. (2008) \\
M. yellowstonensis & $15-22$ & $\mathrm{Y}^{\mathrm{c}}$ & Jay et al. (2011) \\
Vulcanisaeta spp. & $13-15$ & $\mathrm{~N}$ & Jay et al. (2011) \\
Acidilobus spp. & $5-10$ & $\mathrm{~N}$ & Kozubal et al. (2012b) \\
Hydrogenobaculum spp. & $2-3$ & $\mathrm{Y}$ & \\
Other & $<2$ & & Kozubal et al. (2012b) \\
BE_D (T=68 C, pH =3.0) & $35-40$ & $\mathrm{Y}$ & Kozubal et al. (2008) \\
Novel Archaeal Group 2 & $20-25$ & $\mathrm{Y}^{\mathrm{c}}$ & Kozubal et al. (2012b) \\
M. yellowstonensis & $5-10$ & $\mathrm{Y}^{\mathrm{c}}$ & Inskeep et al. (2010) \\
Sulfolobales_MK5 & $5-10$ & $\mathrm{Y}$ & Beam et al. (2013) \\
Thermoplasmatales-like & $5-10$ & $\mathrm{Y}$ & Kozubal et al., (2012a) \\
Thaumarchaeota & $3-5$ & $\mathrm{~N}$ & Inskeep et al. (2010) \\
Novel Archaea group 1 & $3-5$ & $\mathrm{Y}$ & Inskeep et al. (2010) \\
Acidilobus spp. & $3-5$ & & \\
Hydrogenobaculum spp. & $<2$ & & \\
Other & 25 & \\
\hline
\end{tabular}

The presence or absence of haem copper oxidases $(\mathrm{HCO})$ used for the reduction of oxygen in aerobic respiration is summarized.

a. Estimated abundance based on phylogenetic classificatio of contigs ( $>4000 \mathrm{bp}$ ) from assembled metagenome sequence (see references cited).

b. Yes/No is based on the presence or absence of a terminal oxidase complex containing a subunit I haem Cu oxidase (HCO).

c. Contains a Fox terminal oxidase complex specifi for Fe(II)-oxidation in the Sulfolobales (Kozubal et al., 2011; 2012a).

$2012 b$; Inskeep et al., 2010) to range from 12-23\% of the community using different molecular approaches (summarized in Table 2). Another aerobic Fe(II)-oxidizing organism from the BE site $\mathrm{Fe}$ (III)-oxide mat is the Sulfolobales strain MK5 confirme to be an $\mathrm{Fe}(\mathrm{II})$-oxidizing organism in culture and by the presence of a Fox terminal oxidase complex (Kozubal et al., 2012b).

Correlation of oxygen consumption and $\mathrm{Fe}(\mathrm{III})-$ oxide deposition rates coupled with expression of $\mathrm{Fe}(\mathrm{II})$-oxidizing haem $\mathrm{Cu}$ oxidases (foxA) from M. yellowstonensis-like organisms provides direct evidence for the linkage between the activity of this population and measured $\mathrm{O}_{2}$ profile across a mat depth of approximately $700 \mu \mathrm{m}$. However, a significan percentage of the total $\mathrm{O}_{2}$ consumption is due to other aerobic members present in these communities. For example, microbially mediated As(III) oxidation by Hydrogenobaculum sp. (order Aquificale) represents another $\mathrm{O}_{2}$ consuming process (Table 2) that has been reported in other studies (Langner et al., 2001; Macur et al., 2004; Hamamura et al., 2009). Estimated arsenite oxidation rates in these same $\mathrm{Fe}(\mathrm{III})$-oxide mat systems are $0.26 \times 10^{-5}$ and $1.95 \times 10^{-5} \mu \mathrm{mol} \mathrm{As}$ (III) $\mathrm{cm}^{-2} \mathrm{~s}^{-1}$ for BE_D and OSP_B respectively [ $\mathrm{Fe}$ (III) accretion rates scaled by $\mathrm{As}^{\vee}$ : Fe ${ }^{\mathrm{III}}$ mole ratios 0.65] (Inskeep et al., 2004). Stoichiometrically, this corresponds to oxygen consumption rates of $0.13 \times 10^{-5}$ and $0.98 \times 10^{-5} \mu \mathrm{mol} \mathrm{O}_{2} \mathrm{~cm}^{-2} \mathrm{~s}^{-1}$ for BE_D and OSP_B, which represents approximately 0.8 and $6.9 \%$ of the net areal $\mathrm{O}_{2}$ consumption directly measured in BE_D and OSP_B respectively.
The dominant members of the OSP_B and BE_D $\mathrm{Fe}$ (III)-oxide microbial mats also include representatives from two novel lineages in the Archaea (Kozubal et al., 2012a; 2012b) (Table 2). The 'novel archaeal group 1' (NAG1) population is in higher abundance at OSP_B, while the 'novel archaeal group 2' lineages are more abundant in BE_D. However, all of these community members appear to be aerobic chemoorganotrophs based on the presence of terminal oxidase complexes including the subunit I HCO (Inskeep et al., 2010; Kozubal et al., 2012a,b). Although de novo sequence assemblies of NAG1 show no evidence of $\mathrm{Fe}(\mathrm{II})$-oxidation genes, the population appears capable of aerobic oxidation of complex carbon and $\mathrm{CO}$ as potential energy sources (Kozubal et al., 2012a). The Desulfurococcales and Thermoproteales-like populations present in OSP_B and BE_D do not likely respire on $\mathrm{O}_{2}$, based on the absence of haem $\mathrm{Cu}$ oxidases in de novo assemblies from these sites (Inskeep et al., 2010; Jay et al., 2011) as well as the fact that most cultured organisms from these orders are strict anaerobes that often require reduced forms of sulfur (Jay et al., 2011).

\section{Oxygen mass-transfer limitations}

The rapid biotic consumption of $\mathrm{O}_{2}$ in these $\mathrm{Fe}(\mathrm{II})$ oxidizing biofilm is ultimately limited by the diffusive mass transfer rates through the $\mathrm{Fe}$ (III)-oxide matrix. Estimates of the first-orde Thiele modulus (used as a single data fittin parameter) allowed quantificatio of time 
scales for oxygen consumption rates relative to mass transfer (diffusion) rates, and suggested that the system is mass transfer limited with regards to dissolved $\mathrm{O}_{2}$. The rapid rates of $\mathrm{O}_{2}$ consumption are consistent with the importance of terminal oxidase complexes found in the organisms inhabiting these Fe mats (Inskeep et al., 2010; Kozubal et al., 2012a,b). However, the biomineralization and evolution of an $\mathrm{Fe}(\mathrm{III})$-oxide biofil (matrix) results in a diffusion-limited system that exhibits a pronounced gradient in dissolved $\mathrm{O}_{2}$ from bulk-aqueous levels of $\sim 50-60 \mu \mathrm{M}$ to below detection $(<0.3 \mu \mathrm{M})$, all within approximately $700 \mu \mathrm{m}$. Given that the top of these mineralized structures contain the most oxygen, it is expected that $\mathrm{Fe}$ (II)-oxidation rates are greater near the aqueous-mat interface. Evidence for this hypothesis was obtained for OSP_B; however, foxA transcripts were nearly equally abundant throughout the entire depth of BE_D Fe(III)-oxide mats. Certainly, the Fe-oxide mats studied here also exhibit heterogeneity that could contribute to differential $\mathrm{O}_{2}$ diffusion rates to lower mat depths (e.g. preferential versus restricted convective or diffusive transport, Fig. 3).

\section{Biological iron-cycling}

Acidic geothermal springs in NGB are anoxic at the source and $\mathrm{Fe}$ (II)-oxidizing microbial communities do not occur until the springs have sufficient dissolved $\mathrm{O}_{2}$ from atmospheric mixing, after dissolved sulfid has degassed. Abiotic $\mathrm{Fe}$ (II)-oxidation in the springs is negligible in contrast to the microbially mediated process at these $\mathrm{pH}$ values (Singer and Stumm, 1970). Anaerobic Fe(II)oxidation has not been observed in situ. In fact, the $\Delta \mathrm{G}_{\mathrm{rxn}}$ for the reduction of nitrate $\left[8 \mathrm{Fe}(\mathrm{II})+\mathrm{NO}_{3}{ }^{-}+21 \mathrm{H}_{2} \mathrm{O}=\right.$ $\left.8 \mathrm{Fe}(\mathrm{OH})_{3}(\mathrm{~s})+14 \mathrm{H}^{+}+\mathrm{NH}_{4}^{+}\right]$has been shown to be endergonic and would not be expected to be a dominant metabolism in these systems (Inskeep et al., 2005). Therefore, $\mathrm{Fe}(\mathrm{II})$-oxidation is a direct result of aerobic members of the orders Sulfolobales (e.g. M. yellowstonensis and Sulfolobales MK5-like organisms).

The reduction of $\mathrm{Fe}(\mathrm{III})$-oxides has not been measured directly in these iron mats, however, this process cannot be ruled out. Prior work on these systems shows other community members that may contribute to the reduction of $\mathrm{Fe}$ (III)-oxides including Sulfolobales strain MK5 (Kozubal et al., 2012b). The predominant geochemical process in these environments is $\mathrm{Fe}(\mathrm{III}$-oxidation as evinced from several important observations that have preceded this work. First, depth-wise mineralogical characterization of these amorphous iron oxides revealed no transformation to other Fe oxide phases (e.g. magnetite) (Inskeep et al., 2004; Kozubal et al., 2012b), which is a likely indicator that $\mathrm{Fe}$ (III)-reduction does not contribute significantl to losses of $\mathrm{Fe}(\mathrm{III})$. Second, these mats contain very few bacteria and prior 16S rRNA gene surveys show no evidence of known $\mathrm{Fe}$ (III)-reducing populations (Inskeep et al., 2010; Kozubal et al., 2012b). Additionally, no outer membrane cytochromes known to catalyse $\mathrm{Fe}$ (III)-reduction have been found in metagenomes from these sites (Inskeep et al., 2010).

\section{Conclusion}

Results from this study highlight the importance of a potentially limiting substrate (dissolved oxygen) for microbial metabolism at high temperatures and the subsequent aerobic biomineralization of $\mathrm{Fe}$ (III)-oxide phases in acidic springs of YNP. These biotic oxygen-sinks are ultimately limited by the mass transfer of $\mathrm{O}_{2}$ through the $\mathrm{Fe}(\mathrm{III})$-oxide matrix. The consumption of $\mathrm{O}_{2}$ is a multiscale process spanning molecular, cellular and macroscopic (pore-scale) regimes. Measured $\mathrm{O}_{2}$ depth-profile in two acidic springs of Norris Geyser Basin reveal a define spatial zone where the majority of oxygenconsuming reactions are occurring. The spatial abundance of an established $\mathrm{Fe}$ (II)-oxidizing community member ( $M$. yellowstonensis) was shown to correlate with the presence of dissolved oxygen and we expect the same will be true for other aerobic heterotrophs containing terminal oxidase complexes that require oxygen as a terminal electron acceptor (Table 2). The formation of microbial structures (e.g. mats, biofilms containing $\mathrm{Fe}(\mathrm{III})$-oxides via biomineralization is inextricably linked to the diffusive transport of oxygen, which also define a pronounced gradient of dissolved oxygen in the top $\sim 700 \mu \mathrm{m}$ of $\mathrm{Fe}$ (III)-oxide microbial mat.

\section{Experimental procedures}

\section{Site description and geochemistry}

Two iron-oxide microbial mats from NGB were chosen for this study: Beowulf Spring, east discharge, position D (BE_D) and One Hundred Springs Plains, position B (OSP_B) (Fig. 1, Table 1). These sites were prime candidates for this study due to prior detailed geochemical, physical, and microbiological characterization (Inskeep et al., 2004; 2005; 2010; Kozubal et al., 2008; 2011). Beowulf Spring is a heavily terraced iron-oxide mat system flowin north on a relatively steepgrade, whereas OSP Spring is a slower (pulse-type) stream channel flowin southwest on a lower grade that yields a shallower, lower-velocity system. The coordinates of the study sites are: BE_D (44 $\left.43^{\prime} 53.224^{\prime \prime} \mathrm{N}, 110^{\circ} 42^{\prime} 40.727^{\prime \prime} \mathrm{W}\right)$ and OSP_B $\left(44^{\circ} 43^{\prime} 58.8^{\prime \prime} \mathrm{N}, 110^{\circ} 42^{\prime} 32.1^{\prime \prime} \mathrm{W}\right)$. Temperature was measured with a digital thermometer equipped with a T-type thermocouple (Omega Engineering) with an error of \pm $1^{\circ} \mathrm{C}$. A portable Accumet ${ }^{\circledR} \mathrm{AP} 71 \mathrm{pH} / \mathrm{mV} /{ }^{\circ} \mathrm{C}$ meter (Fisher Scientific was used to measure $\mathrm{pH}$ and was calibrated in the fiel using $\mathrm{pH}$ standards of 4.01 and 7.0. Dissolved oxygen, aqueous $\mathrm{CO}_{2}$, total sulfide and ferrous-ferric iron were measured from duplicate samples in the fiel as previously 
described using gas chromatographic and colorimetric methods (Inskeep, et al., 2005).

\section{Oxygen profile}

Dissolved $\mathrm{O}_{2}$ profile were obtained in the direction normal to the bulk flo and surface of the mat (i.e. the aqueous-mat interface). All profile were taken with high-temperature tolerant $50 \mu \mathrm{m}$ (tip diameter) Clark-type microsensors (custom equipment provided by Unisense A/S, Aarhus DK). The $\mathrm{O}_{2}$ consumption rate by the microsensors was estimated at $8 \times 10^{-3} \mu \mathrm{mol}$ year ${ }^{-1}$, which was considered negligible. Sensor positioning was controlled with a micromanipulator coupled to a motor controller. The micromanipulator was housed on a custom, adjustable tripod stand that was used in the fiel to perform profil measurements. Data collection and positioning controls were performed with Sensor TracePro software (Unisense). Sensors were individually calibrated in the field using the anoxic calibration point from either $100 \mathrm{mM} \mathrm{Na} \mathrm{N}_{2}(\mathrm{pH}=10)$ or by positioning the sensor inside the iron-oxide mat where the oxygen signal was less than $5 \%$ of the bulk liquid value (e.g. near detection). The oxic calibration point was obtained by positioning the sensor in the bulk liquid directly above the Fe-oxide mat; this value was also confirme using independent measurements obtained by the Winkler method. The $\mathrm{O}_{2}$ saturation values were also directly measured by the Winkler method by aerating $100 \mathrm{ml}$ spring water at $\sim 1$ LPM inside a beaker (incubated at $75^{\circ} \mathrm{C}$ inside the spring) connected to an air pump and air stone. All profile were performed in triplicate (three positions within $\mathrm{a} \sim 2 \mathrm{~cm}$ radius of each other) for each sample site. Triplicate technical replicates were done for profile taken in the OSP_B site, however the brittle nature of the mat at BE_D only allowed for a single accurate profil per position. Locations corresponding to the surface of the mat were confirme both visually and by initial changes in the profil slope.

\section{Calculations and modelling}

Classical reaction and diffusion theory was used to quantitatively analyse coupled reaction and mass transfer rates. Reaction and diffusion of substrates in microbial mats, biofilm and catalyst materials has been studied extensively (Thiele, 1939; Williamson and Mccarty, 1976; Karel and Robertson, 1987; Stewart and Raquepas, 1995; Stewart, 2003). Briefl , by assuming a steady-state mass balance and one-dimensional slab geometry, Fick's law was used as a basis for modelling the experimental data and the empirical analysis of the bulk $\mathrm{O}_{2}$ flux The model was simplifie by assuming constant effective diffusion constants and a singular reaction term which represents the sum of all $\mathrm{O}_{2}$ consuming processes. The volumetric reaction rate was assumed to be bounded by either a first-orde $\left(R=k_{1} C_{\mathrm{O}_{2}}\right)$ or zero-order rate expression $\left(R=k_{0}\right)$. Dimensionless parameters were define as:

$$
u=C_{\mathrm{O}_{2}} / C_{\mathrm{O}_{2}}{ }^{\prime}, \quad \zeta=z / L_{\mathrm{f}}, \quad \varphi_{\mathrm{o}}{ }^{2}=k_{\mathrm{o}} L_{\mathrm{f}} / C_{\mathrm{O}_{2}}{ }^{\prime} D_{\mathrm{e}}, \quad \varphi_{1}{ }^{2}=k_{1} L_{\mathrm{f}}{ }^{2} / D_{\mathrm{e}}
$$

where $u$ is the ratio of the observed dissolved $\mathrm{O}_{2}$ concentrations in the mat relative to the bulk liquid, $\zeta$ is the dimensionless depth parameter, $z$ is the depth-position within the mat, $L_{\mathrm{f}}$ is the total depth of the $\mathrm{Fe}$ (III)-oxide mat, $\phi$ is the Thiele modulus, a dimensionless rate constant define using a ratio of the reaction rate coefficient to the effective diffusion coefficient $\left(D_{\mathrm{e}}\right)$ scaled to a characteristic area $\left(L_{\mathrm{f}}^{2}\right)$ (Thiele, 1939). Actual $L_{f}$ values were obtained either by microscopy of excised mat sections (site BE_D) and by direct measurement of iron oxide mat accretion samples under steady-state conditions (site OSP_B) (see Results and Discussion). The effective diffusion coefficient of $\mathrm{O}_{2}$ in the iron oxide microbial mat matrix is not known nor easily measured; consequently, the Thiele modulus is a useful parameter, which is inversely proportional to $D_{\text {e }}$.

Dimensionless analytical solutions (Eqs 1 and 2) to differential mass balances were obtained by imposing a zero-flu boundary condition at the bottom of the mat $\left(z=L_{f}\right)$ and setting the observed concentration of dissolved $\mathrm{O}_{2}$ to the constant bulk liquid concentration at the top of the mat $(z=0)$.

$$
\begin{aligned}
& u=\cosh \left(\varphi_{1} \cdot \zeta\right)-\tanh \left(\varphi_{1}\right) \sinh \left(\varphi_{1} \cdot \zeta\right) \\
& u=\left(\varphi_{\circ}^{2} \cdot \zeta^{2}\right) / 2-\varphi_{\circ}^{2} \cdot \zeta+1
\end{aligned}
$$

Equations 1 and 2 are the analytical solutions for the firs and zero-order reaction models, respectively. The analytical solutions were used to $\mathrm{fi}_{2} \mathrm{O}_{2}$ profil data (non-linear least squares regression) resulting in estimates of the Thiele moduli. Detailed and step-wise interpretations of the reaction-diffusion models and dimensionless number interpretations are contained in Appendix S1 of this manuscript.

\section{Iron oxide accretion rates}

Glass microscope slides $(75 \times 25 \times 1 \mathrm{~mm})$ were cleaned in a $2 \%$ hydrochloric acid bath for $\sim 2 \mathrm{~h}$ to remove organic carbon, rinsed in $18 \mathrm{M} \Omega \mathrm{H}_{2} \mathrm{O}$ (free of organic carbon), and autoclaved for $15 \mathrm{~min}$. The cleaned slides were placed in the primary outflo channel of OSP_B $\left(73^{\circ} \mathrm{C}\right)$ and BE_D $\left(68^{\circ} \mathrm{C}\right)$ such that the $75 \times 25 \mathrm{~mm}$ surface was exposed to flo and visually flus with the mat surface (see Fig. S1). Slides were carefully removed at $7,15,28$ and 133 days, rinsed in bulk stream water to remove non-adhered material and placed in $0.175 \mathrm{M}$ ammonium oxalate buffer $(\mathrm{pH}=3)$ to dissolve Fe-oxides (Loeppert and Inskeep, 1996). Temperatures at these spring conditions remained relatively constant $\left( \pm 2^{\circ} \mathrm{C}\right)$ over the timescale of the experiment. Ferrous and total soluble iron were measured using the Ferrozine method at an absorbance of $562 \mathrm{~nm}$ (Stookey, 1970).

\section{Microscopy}

Images of thin sections from excised Fe(III)-oxide mat were taken with a stereo microscope (Nikon SMZ1500). Excised mat samples from BE_D were embedded with epoxy under a vacuum and thin sectioned. Stereoscope images were calibrated by direct measurement with a $1 \mathrm{~mm}$ stage micrometer. Scanning electron micrographs were obtained of slides sampled from fiel incubations with a fiel emission-scanning electron microscope set at low voltage $(1 \mathrm{kV})$ after sputtercoating with Ir to minimize charging. 


\section{Quantitative PCR and spatial mRNA analysis}

The relative spatial abundance of Metallosphaera yellowstonensis strain MK1 16S rRNA gene (1 copy per chromosome) was determined by slicing $1 \mathrm{~mm}$ from the top of an excised portion of mat. The remainder of the mat, known to contain lower levels of oxygen, was termed 'bottom-mat'. Community DNA was extracted from both top and bottom samples using the FastDNA SPIN Kit for Soil (MP Biomedicals, LLC, OH). Quantitative PCR ( $\mathrm{PPCR}$ ) was performed using M. yellowstonensis specifi 16S rRNA gene primer and the Sso Fast EvaGreen qPCR Kit and protocol in $50 \mu$ reactions (Bio-Rad) on a RotorGene 3000 qPCR machine (Corbett Research). The specifi primer and reaction conditions were as previously described (Kozubal et al., 2008). Statistical analysis was performed using an independent, two-tailed Student's $t$-test.

Iron-oxide microbial mat squares (approximately $2 \times 2 \mathrm{~cm}$ ) were excised at the position where microsensor measurements were made for each sampling position. The mat sections were placed in sterile Petri dishes and sliced into 'tops' and 'bottoms' in same fashion as described in the qPCR section. All mat samples were stored in RNA Later in RNase free tubes. Total RNA was extracted (in triplicate) from approximately $500 \mathrm{mg}$ of cut microbial mat using the FastRNA ${ }^{\circledR}$ Pro Soil Direct Kit (Qbiogene, CA) and FastPrep ${ }^{\circledR}$ Instrument (Qbiogene), for $40 \mathrm{~s}$ at a speed setting of 6.0. Total RNA was then treated with RNase free DNase I (New England Biolabs, MA) for $15 \mathrm{~min}$ and $37^{\circ} \mathrm{C}$. The DNase I reaction was terminated by precipitation of total RNA with nuclease free lithium chloride (fina concentration $1.6 \mathrm{M}$ ) and absolute ethanol overnight (Sambrook and Russell, 2001). RNA was resuspended in nuclease free water after centrifugation at $4^{\circ} \mathrm{C}$ for $15 \mathrm{~min}$ and washing once in ice cold $70 \%$ ethanol. The terminal haem copper oxidase subunit I (foxA) specifi to the iron oxidation pathway of $M$. yellowstonensis was reverse transcribed using the AccessQuick RT-PCR System and protocol (Promega) with M. yellowstonensis specifi foxA primers (Kozubal et al., 2011). The cDNA foxA amplicons were purifie with the GenElute $^{\mathrm{TM}}$ PCR CleanUp Kit (Sigma-Aldrich). The qPCR reaction was the same as for the 16S rRNA gene from M. yellowstonensis as described in the above section. Relative expression was determined by comparing the observed $\mathrm{C}_{\mathrm{T}}$ values of foxA and M. yellowstonensis 16S rRNA gene (Kozubal et al., 2011). Statistical analysis was performed as described in the above section.

\section{Acknowledgements}

The authors acknowledge funding from the National Science Foundation-Integrative Graduate and Education Training (IGERT) Program (DGE 0654336) for support to H.C.B. and J.P.B. and the Department of Energy-Genome Science Program, Microbial Interactions Foundational Science Focus Area (Pacifi Northwest National Laboratory subcontract 112443 to M.S.U.). Additional support was provided by Unisense A/S (Aarhus, DK), the DOE-Joint Genome Institute Community Sequencing Program (CSP 787081), E. Booth for building customized fiel equipment, C. Hendrix and S. Gunther (YNP Center for Resources) for research permit administration, and Drs. P. Stewart, M. Kühl and Mr. S. Davis for helpful discussions and fiel assistance.

\section{References}

Auernik, K.S., and Kelly, R.M. (2008) Identificatio of components of electron transport chains in the extremely thermoacidophilic crenarchaeon Metallosphaera sedula through iron and sulfur compound oxidation transcriptomes. Appl Environ Microbiol 74: 7723-7732.

Baker, B.J., and Banfield J.F. (2003) Microbial communities in acid mine drainage. FEMS Microbiol Ecol 44: 139-152.

Bathe, S., and Norris, P.R. (2007) Ferrous iron- and sulfurinduced genes in Sulfolobus metallicus. Appl Environ Microbiol 73: 2491-2497.

Beam, J.P., Bernstein, H.C., Kozubal, M., Carlson, R.P., and Inskeep, W.P. (2011) Distribution and activity of ironoxidizing microorganisms in acidic geothermal environments. Goldschmidt Conference, August 15-19, 2011, Prague, CR. Mineral Mag 75: 503.

Beam, J.P., Jay, Z., Kozubal, M., and Inskeep, W.P. (2013) Novel thermoacidophilic Thaumarchaeota inhabit iron oxide and elemental sulfur sediment habitats of Yellowstone National Park. ISME J (submitted).

de Beer, D., Stoodley, P., Roe, F., and Lewandowski, Z. (1994) Effects of biofil structures on oxygen distribution and mass-transport. Biotechnol Bioeng 43: 1131-1138.

Druschel, G.K., Emerson, D., Sutka, R., Suchecki, P., and Luther, G.W. (2008) Low-oxygen and chemical kinetic constraints on the geochemical niche of neutrophilic iron(II) oxidizing microorganisms. Geochim Cosmochim Acta 72: 3358-3370.

Emerson, D., and Moyer, C.L. (2002) Neutrophilic Fe-oxidizing bacteria are abundant at the Loihi Seamount hydrothermal vents and play a major role in Fe oxide deposition. Appl Environ Microbiol 68: 3085-3093.

Emerson, D., and Revsbech, N.P. (1994a) Investigation of an Iron-oxidizing microbial mat community located near Aarhus, Denmark: fiel studies. Appl Environ Microbiol 60: 4022-4031.

Emerson, D., and Revsbech, N.P. (1994b) Investigation of an iron-oxidizing microbial mat community located near Aarhus, Denmark: laboratory studies. Appl Environ Microbiol 60: 4032-4038.

Hall-Stoodley, L., Costerton, J.W., and Stoodley, P. (2004) Bacterial biofilms from the natural environment to infectious diseases. Nat Rev Microbiol 2: 95-108.

Hamamura, N., Macur, R.E., Korf, S., Ackerman, G., Taylor, W.P., Kozubal, M., et al. (2009) Linking microbial oxidation of arsenic with detection and phylogenetic analysis of arsenite oxidase genes in diverse geothermal environments. Environl Microbiol 11: 421-431.

Inskeep, W.P., and McDermott, T.R. (2005) Geomicrobiology of Acidsulfate-Chloride Springs in Yellowstone National Park. Bozeman, MT, USA: Montana State University.

Inskeep, W.P., Macur, R.E., Harrison, G., Bostick, B.C., and Fendorf, S. (2004) Biomineralization of $\mathrm{As}(\mathrm{V})$-hydrous ferric oxyhydroxide in microbial mats of an acid-sulfatechloride geothermal spring, Yellowstone National Park. Geochim Cosmochim Acta 68: 3141-3155.

Inskeep, W.P., Ackerman, G.G., Taylor, W.P., Kozubal, M., Korf, S., and Macur, R.E. (2005) On the energetics of 
chemolithotrophy in nonequilibrium systems: case studies of geothermal springs in Yellowstone National Park. Geobiology 3: 297-317.

Inskeep, W.P., Rusch, D.B., Jay, Z.J., Herrgard, M.J., Kozubal, M.A., Richardson, T.H., et al. (2010) Metagenomes from high-temperature chemotrophic systems reveal geochemical controls on microbial community structure and function. PLOS ONE 5: e9773. doi:10.1371/journal. pone.0009773.

Jackson, C.R., Langner, H.W., Donahoe-Christiansen, J., Inskeep, W.P., and McDermott, T.R. (2001) Molecular analysis of microbial community structure in an arseniteoxidizing acidic thermal spring. Environ Microbiol 3: 532542.

Jay, Z.J., Planer-Friedrich, B., Rusch, D.B., and Inskeep, W.P. (2011) Linking geochemistry to microbial community structure and function in sulfidi geothermal systems of Yellowstone National Park. Goldschmidt Conference, August 15-19, 2011, Prague, CR. Mineral Mag 75: 1104.

Kappler, U., Sly, L.I., and McEwan, A.G. (2005) Respiratory gene clusters of Metallosphaera sedula - differential expression and transcriptional organization. Microbiology 151: 35-43.

Karel, S.F., and Robertson, C.R. (1987) Reaction-rate calculations for cosubstrates diffusing into catalyst layer from opposite sides. Biotechnol Bioeng 30: 427-438.

Konhauser, K.O. (1998) Diversity of bacterial iron mineralization. Earth Sci Rev 43: 91-121.

Kozubal, M., Macur, R.E., Korf, S., Taylor, W.P., Ackerman, G.G., Nagy, A., and Inskeep, W.P. (2008) Isolation and distribution of a novel iron-oxidizing crenarchaeon from acidic geothermal springs in Yellowstone National Park. Appl Environ Microbiol 74: 942-949.

Kozubal, M.A., Romine, M., deM Jennings, R., Jay, Z.J., Tringe, S.G., Rusch, D.B., et al. (2012a) Geoarchaeota: a new candidate phylum in the Archaea from hightemperature acidic iron mats in Yellowstone National Park. ISME J. doi:10.1038/ismej.2012.132.

Kozubal, M.A., Macur, R.E., Jay, Z.J., Beam, J.P., Malfatti, S.A., Tringe, S.G., et al. (2012b) Microbial iron cycling in acidic geothermal springs of Yellowstone National Park: integrating molecular surveys, geochemical processes, and isolation of novel Fe-active microorganisms. Front Microbiol 3: 109.

Kozubal, M.A., Dlakic, M., Macur, R.E., and Inskeep, W.P. (2011) Terminal oxidase diversity and function in 'Metallosphaera yellowstonensis': gene expression and protein modeling suggest mechanisms of $\mathrm{Fe}(\mathrm{II})$ oxidation in the Sulfolobales. Appl Environ Microbiol 77: 1844-1853.

Langner, H.W., Jackson, C.R., McDermott, T.R., and
Inskeep, W.P. (2001) Rapid oxidation of arsenite in a hot spring ecosystem, Yellowstone National Park. Environl Sci Technol 35: 3302-3309.

Loeppert, R.H., and Inskeep, W.P. (1996) Methods of Soil Analysis: Part 3 - Chemical Methods. Madison, WI, USA: Soil Science Society of America and American Society of Agronomy.

Macur, R.E., Langner, H.W., Kocar, B.D., and Inskeep, W.P. (2004) Linking geochemical processes with microbial community analysis: successional dynamics in an arsenic-rich, acid-sulphate-chloride geothermal spring. Geobiology 2: 163-177.

Revsbech, N.P., and Jorgensen, B.B. (1986) Microelectrodes - their use in microbial ecology. Adv Microbl Ecol 9: 293352.

Sambrook, J., and Russell, D.W. (2001) Molecular Cloning: A Laboratory Manual. Cold Spring Harbor, NY, USA: Cold Spring Harbor Laboratory Press.

Singer, P.C., and Stumm, W. (1970) Acidic mine drainage: the rate-determining step. Science 167: 1121-1123.

Sobolev, D., and Roden, E.E. (2001) Suboxic deposition of ferric iron by bacteria in opposing gradients of $\mathrm{Fe}(\mathrm{II})$ and oxygen at circumneutral pH. Appl Environ Microbiol 67: 1328-1334.

Stewart, P.S. (2003) Diffusion in biofilms J Bacteriol 185: 1485-1491.

Stewart, P.S., and Raquepas, J.B. (1995) Implications of reaction-diffusion theory for the disinfection of microbial biofilm by reactive antimicrobial agents. Chem Eng Sci 50: 3099-3104.

Stookey, L.L. (1970) Ferrozine - a new spectrophotometric reagent for iron. Anal Chem 42: 779-781.

Thiele, E.W. (1939) Relation between catalytic activity and size of particle. Ind Eng Chem 31: 916-920.

Wilke, C.R., and Chang, P. (1955) Correlation of diffusion coefficients in dilute solutions. AlChE J 1: 264-270.

Williamson, K., and McCarty, P.L. (1976) Model of substrate utilization by bacterial films $J$ Water Pollut Control Fed 48: 9-24.

\section{Supporting information}

Additional Supporting Information may be found in the online version of this article at the publisher's web-site:

Appendix S1. Supplementary modelling methodology. Fig. S1. Photograph of in situ incubated glass microscope slides over 28 total days of biomineralization from OSP_B and BE_D. Scale bar $=2.5 \mathrm{~cm}$. 